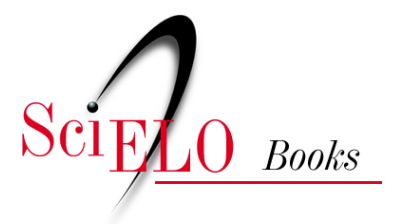

\title{
Prefácio
}

\section{Marcelo Medeiros}

\section{SciELO Books / SciELO Livros / SciELO Libros}

MEDEIROS, M. Prefácio. In: ROCHA, E.F. O negro no mundo dos ricos: um estudo sobre a disparidade racial de riqueza com os dados do Censo 2010 [online]. Brasília: Editora UnB, 2019, pp. 11-14. Pesquisa, inovação \& ousadia series. ISBN: 978-65-5846-052-7. https://doi.org/10.7476/9786558460527.0001.

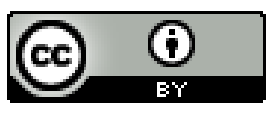

All the contents of this work, except where otherwise noted, is licensed under a Creative Commons Attribution 4.0 International license.

Todo o conteúdo deste trabalho, exceto quando houver ressalva, é publicado sob a licença Creative Commons Atribição 4.0.

Todo el contenido de esta obra, excepto donde se indique lo contrario, está bajo licencia de la licencia Creative Commons Reconocimento 4.0. 


\section{Prefácio}

O Brasil é um país construído sobre desigualdades raciais. E foi já em seus primeiros passos no país que a Sociologia levou isso a sério. O livro de Emerson Rocha é um debate com uma tradição longa e um problema perene da história brasileira. Seu esforço é por explicar por que a renda dos negros é menor que a dos brancos. O caminho para isso é olhar para os ricos. A lógica é simples, se os ricos detêm a maior fração da renda, uma parte grande da desigualdade pode ter origem em diferenças no topo da distribuição. Diferentemente de muito que foi feito sobre desigualdade racial no Brasil, o foco de Emerson não é na pobreza, mas nas diferenças nos níveis de riqueza e na formação de elites. O que não falta a este livro é mérito.

O assunto é extremamente importante: riqueza é poder, um poder que define os destinos das pessoas. Mais do que simplesmente perguntar por que é tão difícil para um negro ser rico, o autor, no fundo, está preocupado em identificar quem tem poder no Brasil, o porquê desse poder ser tão concentrado e as razões para isso não ter mudado como deveria. Não é apenas um livro sobre relações raciais, é um livro sobre hierarquias quase perpétuas.

Há vários tipos de igualdade desejável, uns mais, outros menos ambiciosos. As disparidades raciais são um sinal claro da falta de igualdade mais elementar, a de oportunidades: as chances de se encontrar uma negra no topo da distribuição são muito menores do que as de se encontrar um branco. Além disso, o conjunto de negros no topo é mais pobre que o dos brancos. Em praticamente tudo que se refere 
a hierarquia, a população negra está em condições piores e, mesmo nos casos em que as condições iniciais são niveladas, o racismo aparece como freio que contém os negros que superam obstáculos, um peso que os impede de alçar voo.

O que, exatamente, está por trás disso, não se sabe bem. Se uma parte é herança de um passado infame, certamente há, ainda hoje, forças que são inaceitáveis atuando. Os negros não são meros escravos de um passado escravista, são também escravos de um presente racista. Seu acesso ao poder para mudar isso, lembra o livro, é limitado por ações difusas e raramente explícitas: discriminação no sistema de ensino, no mercado de trabalho, na imprensa e nas artes, na estética, nas regras culturais de formação de família, em muitos costumes e, talvez principalmente, na resistência conveniente de um deixe-estar em relação às desigualdades raciais que ignora a existência do problema ou se recusa a enfrentá-lo. As desigualdades raciais não são o único problema do país, mas isso não faz com que deixem de ser um problema fundamental.

Para tratar desse problema o livro é um ponto de partida e um ponto de chegada. De partida porque abre as portas da exploração de coisas novas, sobre as quais conhecemos pouco, mas que a intuição sugere ser caminhos promissores para se entender por que a população negra está em desvantagem, tão grande e tão sistemática, em relação à branca. E de chegada porque apresenta conclusões sólidas e confiáveis para que sobre elas se construam argumentos e interpretações.

Porém, nenhum ponto de chegada é definitivo, e nisso o livro não é ingênuo, nem arrogante: trata o que faz como algo que um dia pode ser revisto, mas cuja revisão exigirá um trabalho da mesma qualidade. Emerson é honesto, aponta sempre que pode as vulnerabilidades do que faz, e foge initerruptamente da interpretação rasteira. Assim como não espera que ninguém negue o papel que a raça tem na manutenção da desigualdade no Brasil, tampouco nega ele a importância da origem social que limita a ascensão dos negros. Uma de suas ideias, aliás, é de que uma trança de várias coisas, algumas das quais nem conhecemos direito, é o que faz a desigualdade brasileira ser tão alta. 
O argumento principal do livro é o de que existe um conjunto de forças que resiste à presença de negros no topo da hierarquia social. Não é um impedimento, no sentido de restrição absoluta, mas uma limitação que torna essa presença difícil. A consequência disso é que os negros podem avançar, mas há uma fronteira para isso. Nos termos do livro, funcionam no Brasil mecanismos de acomodação das relações raciais em posições de classe. Em termos mais mundanos, negros são bem-vindos, desde que saibam seu lugar, e que esse lugar não seja muito alto. Esse conjunto difuso de forças limitantes, que geralmente embalamos no pacote chamado discriminação, cresce à medida que se avança nas hierarquias. Ou seja, a discriminação é maior quanto mais ricos vão se tornando os negros.

Esse jogo entre classe e raça vai na direção oposta das teorias de branqueamento por enriquecimento. Um negro rico não é branco, é um negro que ocupa uma posição de classe mais alta do que brancos pobres, mas ainda assim em desvantagem em relação aos brancos ricos. A classe dá status positivo, mas o efeito da raça é negativo. Para o negro mais rico, aliás, é maior a desvantagem. Nos pontos mais altos da distribuição de renda é mais difícil para as pessoas negras transformar seus recursos pessoais em riqueza - a educação dos negros, por exemplo, é menos valorizada que a dos brancos. A das mulheres negras, então, vale ainda menos. Nos casos em que a valorização é similar, como nas formações profissionais de elite, os gargalos de entrada são tão severos que a presença de negros é muito baixa. Muita igualdade se ganharia se a entrada nesses níveis educacionais fosse maior, mas isso tampouco seria uma panaceia.

Em consonância com boa parte da literatura sobre ricos no Brasil, Emerson encontra que os fatores que explicam as disparidades raciais de riqueza não são os mesmos que explicam diferenciais no resto da distribuição. Por essa razão, aquilo que na média explica parte das desigualdades raciais de renda não serve bem para explicar as desigualdades no topo. Podem haver fatores regulares que determinam em que medida um negro pode se tornar rico, mas esses fatores não são bem observados pelas pesquisas de que dispomos. 
O negro no mundo dos ricos

Assim, quanto maior o nível de renda, maiores as implicações da discriminação contra a população negra e, portanto, maior a dificuldade para superá-la. São os mecanismos de acomodação das relações sociais em ação: tolerância na base, mas resistência no topo.

Marcelo Medeiros 